\title{
How to Manage Generations? An Approach based on the Quality of Work Life
}

\author{
Laura MARTÍNEZ-BUELVAS ${ }^{1}$ and Olga JARAMILLO-NARANJO ${ }^{2}$ \\ ${ }^{1}$ Industrial Engineer Department - Universidad Tecnológica de Bolívar, Cartagena, Colombia \\ ${ }^{2}$ School of Business - Universidad Del Norte, Barranquilla, Colombia \\ Correspondence should be addressed to: Laura MARTÍNEZ-BUELVAS; Imartinez@utb.edu.co \\ Received date:6 February 2019; Accepted date:11 May 2019; Published date: 27 August 2019 \\ Academic Editor: Cassia Bomer Galvao
}

Copyright (C) 2019. Laura MARTÍNEZ-BUELVAS and Olga JARAMILLO-NARANJO. Distributed under Creative Commons CC-BY 4.0

\begin{abstract}
The objectives of this research are to examine whether there are significant differences in the perception of quality of work life among employees of three generational cohorts (i.e., Baby Boomers, Generation Xers and Millennials) and to propose some strategies from HRM in order to manage these differences. We used survey data collected from 522 employees of the logistic sector in Colombia and conducted internal consistency analysis, correlation analyses and one-way ANOVA. Results of ANOVA indicate that variables of quality of work life significantly differ depending on the generational membership of the employees. For example, Millennials were found to be a more distinct cohort from Gen Xers and Baby Boomers in terms of their relationship between promotion and career. However, the results suggest that employees in the older generations are likely to be more dedicated to, engrossed in, and even vigorous at work. For future studies, we recommend discussing how the knowledge on each generation in the workplace can inform specific HRM practices, such as how to train each generation effectively or to encourage each generation to improve work performance.
\end{abstract}

Keywords: Quality of work life, Generational differences, Baby boomers, Generation X, Millennials, Generation Y

\section{Introduction}

Human Resources Management (HRM) is defined as a strategic and coherent approach to the management of an organization's most valued assets; the people working there who individually and collectively contribute to the achievement of its objective. In this sense, the main tasks of HRM are to create human capital in organizations and facilitate high performance workplaces in order to create 
competitive advantage (Kultalahti \& Liisa Viitala, 2014). However, human resources managers have many challenges since they must respond to the needs of employees by developing mechanisms regarding their life at work, and managing employees from different generations, because each generation has its own unique values, set of skills, and characteristics (Gursoy, Chi, \& Karadag, 2013)

As the world becomes more competitive, businesses around the world need to provide a good quality of work life in order to attract and retain qualifying employees (Sue Ling, Chang, \& Lien Yin, 2012). Quality of Work Life (QWL) is a concept that emerged in the seventies given the need to humanize working environments, with special attention to development of human resources and the improvement of work environments (Patlán Pérez \& J., 2016). The most classic definitions show a generic conception based on the valuation of the individual in relation to his/her working environment, predominating factors such as job satisfaction, experience in the organization, motivation for employment, personal needs, among others (Segurado Torres \& Agulló Tomás, 2002; Silva, 2006). However, the most recent definitions are characterized by the identification of the QWL with the satisfaction that the job generates to the employee maintaining a focus centered on the individual (MartínezBuelvas, Oviedo-Trespalacios, \& LunaAmaya, 2015; Vélez, 2010). Besides, this concept encompasses different heterogeneous environments in which is conceived: possibility of future in the organization, satisfaction of the work executed, recognition for results obtained, salaries received, benefits offered, human relations in the group and in the organization, psychological and physical environments of work, freedom to decide, among others (Buelvas, OviedoTrespalacios, \& Amaya, 2013; Cardona Echeverri \& Zambrano Cruz, 2014).

Moreover, generational characteristics are formed by shared historical experiences among a group of people of a similar age. In an organizational context, generational characteristics may lead to formulating distinct generational perceptions and values (Schuman \& Scott, 1989). Currently, changes have taken place in the generational composition of the workforce, with the recent joiner Generation $Y$ into workforce, where Baby Boomers and Generation X. dominated it. Each of these cohorts has different expectation in terms of both personal and professional lives, having different values and ways of working (Gursoy et al., 2013)

The objectives of this research are to examine whether there are significant differences in the perception of quality of work life among employees of three generational cohorts (i.e., Baby Boomers, Generation Xers and Millennials) in the logistics sector in Colombia, and to propose some strategies from HRM in order to manage these differences.

\section{Literature Review}

\section{Quality of Work Life}

The study of the Quality of Work Life (QWL) is one of the most researched topics in recent years at international level, motivated by the fact that the global labor situation is going through a crisis moment, where it is observed that the precarious level increases and labor achievements obtained in the last two centuries have decreased, due in large part to capitalism (Bagtasos, 2011; Van der Berg \& Martins, 2013). This concept represents a series of conceptual problems, given that objective factors derived from the environment, the organization and the nature of the task are considered (Quezada, Castro, \& Cabezas, 2010). However, this concept can be complemented by the worker's perspective, who seems important to consider the subjective assessment when describing and investigating aspects that influence their work development (Bagtasos, 2011; Celia \& Karthick, 2012).

The term "Quality of Work Life" was issued in 1970 by Louis Davis, who described the concern that should be raised throughout the organization about the welfare and health of all employees to perform successfully their tasks (Vélez, 2010). Poza 
and Prior define it as the way in which work experience is produced in objective conditions, including aspects such as occupational health or safety, and in subjective conditions of the worker, in the sense how he/she lives it. Likewise, Lau states that QWL is a set of favorable working conditions that protect and promote employee satisfaction through rewards, job security and personal development opportunities. On the other hand, Chiavenato states that QWL represents a multidimensional concept with two antagonistic situations: one part made reference to vindicate the welfare and satisfaction of the employee, and the other, the interest of the organization in terms of the increase of productivity and quality of the products/services offered (Argüelles Ma, Garcia, Fajardo, Medina, \& Maldonado, 2013; Somarriba Arechavala, Merino Llorente, Ramos Truchero, \& Negro Macho, 2010).

Currently, QWL study has been addressed from two theoretical-methodological perspectives: the first evaluates the work environment and the second assesses the psychological perspective (Segurado Torres \& Agulló Tomás, 2002). These differ by the objectives they pursue in their purpose of improving the quality of life at work. The perspective that evaluates the work environment aims to improve the quality of life by achieving organizational interests (Segurado Torres \& Agulló Tomás, 2002; Silva, 2006). Otherwise, the psychological perspective shows greater interest for the worker, developing a detailed analysis of those specific elements that the worker faces. Finally, while the latest theoretical trend points to the importance of the subjective aspects of working life, the perspective of the work environment subordinates such aspects to working conditions and structural elements of the organization (Segurado Torres \& Agulló Tomás, 2002; Silva, 2006).

QWL measurements can use objective or subjective methods. In the objective approximations, physical conditions of the work environment are evaluated through always-quantitative information, provided by the representatives and/or documents coming from the organization. Among the most used instruments are lists, profiles and checklists (Silva, 2006). However, the subjective approach enables the perception, judgment and opinion that employees have regarding their working conditions and work environment. It collects qualitative or quantitative information of individual variables. The most used techniques are observation, interview and questionnaires (Segurado Torres \& Agulló Tomás, 2002).

It is clear that during recent years, the advances made in the field of QWL have paid off and new methodologies and / or tools are currently being considered to evaluate the conditions to which workers are exposed. However, the interesting thing about addressing this issue is to define tools that allow modeling the impact of different variables in the QWL, as a support for decision-making in companies, in relation to the importance of decent work within organizations.

After reviewing the literature around the concept of Quality of Work Life, we can summarize the benefits for both individual and organization as follows (see Table 1): 
Table 1: Benefits of Quality of Work Life (Patlán Pérez \& J., 2016)

\begin{tabular}{|c|c|}
\hline Benefits for the employees & Benefits for the organization \\
\hline $\begin{array}{l}\text { - } \\
\text { - Increased motivation } \\
\text { - } \text { Improvement in physical health } \\
\text { Better performance in the functions of } \\
\text { the job } \\
\text { - } \text { Decrease in stress levels } \\
\text { - } \text { Increngthening innovation and creativity } \\
\text { - } \text { Balance between family and work } \\
\text { Greater personal and professional } \\
\text { - Increase in performance }\end{array}$ & $\begin{array}{l}\text { - } \text { Increase in sales } \\
\text { - } \quad \text { Rotation rate reduction } \\
\text { - } \quad \text { Most reduction attractive organizations for } \\
\text { - } \text { recruitment and selection processes } \\
\text { - } \quad \text { Better work environment } \\
\text { - Lower absenteeism rate } \\
\text { Increase in profitability and } \\
\text { competitiveness }\end{array}$ \\
\hline
\end{tabular}

\section{Generational in the workplace}

Researchers, who study the effects of population on society, use the term "generation" to refer to the people who were born and raised in the same general time span. (Kupperschmidt, 2000). A generation is defined as an identifiable group that shares birth years, age, location and significant life events. This concept has two essential components: "a common location in historical time" and "a distinct consciousness of that historical position" (Tang, Wang, \& Zhang, 2017). Values of a generation tend to be influenced by historical and social life experiences (Wey Smola \& Sutton, 2002). While they exhibit differences, many of whom grew up in the same time period have a strong identification with their own time and may feel, think and act in similar ways. Those similarities tend to be evident in the ways they live their lives, including their participation in the workforce (Gursoy et al., 2013).

Generational impacts on management systems and styles are trending toward the front lines of management literature. Studies suggest that three generations that are most represented in today's workplace: Baby Boomers, Generation $\mathrm{X}$, and Millennials (also known as Gen Y). A brief profile of each generation will be discussed next.
Baby Boomers born between 1946 and1964, this generation is referred to as the Baby Boom generation because of the extra 17 million babies born during that period relative to previous census figures (O'Bannon, 2001). They grew up in the economic prosperity of the post-World War II, and lived through the most dramatic changes in American history, including the civil rights movement, the Vietnam War, and assassinations of John F. Kennedy and Martin Luther King (Gursoy et al., 2013), as well as, they lived the expansion of television in homes, rock and roll, the first man on the moon, the rights of women, the hippie movement, and Woodstock (Zemke, R., Raines, \& Filipczak, 2013). More than anything, work, for Baby Boomers, has been perceived to be much more important part of life than younger generations do. Boomers have been characterized as individuals who believe that hard work and sacrifice are the price to pay for success (Patterson \& Pegg, 2009). Besides, they have also been characterized as being goaloriented. This is a significant tension point between them and the younger generations because they expect others to have the same work ethic and work the same hours. Boomers have been described as motivated to change the world with their idealism and are considered optimistic (Hayes, Parks, McNeilly, \& Johnson, 2018). They are now recognized for their positive attitudes toward work and their abilities to build consensus, mentor, and affect change 
(Dixon, Mercado, \& Knowles, 2013). They are also loyal and accept hierarchical relationship in the workplace (Gursoy et al., 2013). Among their work strengths are the ability to guide, generate and be flexible to change (Kupperschmidt, 2000). They are seen as an essential piece for the process of transferring leadership and authority to the following generations.

Generation X born between 1965 and 1980, they have been shaped by critical political events such as the end of the Cold War and a series of economic recessions in early and late 1970s and early 1980s. They witnessed high unemployment and family relocations caused by economic instability (Twenge \& Campbell, 2003). As a result, Gen Xers tend to be independent and individualistic, place more value on their own careers over being loyal to organizations, and appreciate more pay and material possessions (Wittig-Berman \& Beutell, 2008). Gen Xers tend to be cynical and untrusting, which has been attributed to observing their parents' job losses despite their parents' demonstrated organizational loyalty (Dixon et al., 2013). They were also influenced by events such as: the emergence of personal computers, the expansion of the Internet, the death of John Lennon, Chernobyl, the fall of the Berlin Wall, among others (Zemke et al., 2013). Instead of seeking job security, they pursue challenging jobs and better opportunities to develop their own careers. They also tend to value autonomy and freedom from supervision in the workplace, namely, they tend to be skeptical of the status quo and hierarchical relationship. It is a practical generation, with a pragmatic vision of reality (Kupperschmidt, 2000). They are found to be technologically savvy, informal, quick learners, value work-life balance and embrace diversity (Gursoy et al., 2013). Gen Xers are noted for their willingness to develop skills and apply them effectively. In return, also they expect employers to listen to their needs, provide an enabling culture and structure, and pay fairly (Dixon et al., 2013).
Otherwise, Millennials or Generation $Y$ (born 1981 - 2000) has been characterized by economic prosperity, advancement of instant communication technologies through the Internet (Google and YouTube), social networking (Facebook, Twitter, Instagram, WhatsApp) and globalization. For this reason, they have been provided with more opportunities to study abroad, have been exposed to diverse cultures, and have shaped a lifelong inclination towards learning from multiple sources (Park \& Park, 2018). Similar to Gen Xers, Millennials value freedom and worklife balance more than Baby Boomers do (Twenge \& Campbell, 2003; Wey Smola \& Sutton, 2002). They also have high leisure work values, preferring a job that provides more vacation time, besides, they have higher expectations about promotions and pay raises in the workplace $(\mathrm{Ng}$, Schweitzer, \& Lyons, 2010). They are impatient and innovative, they demand balance between work and their selfinterest, and they are willing to sacrifice financial gains in exchange for significant things (Seaton et al., 2007). Constant experience in the networked world has had a profound impact on their style in approaching problem-solving situations. The advent of interactive media has generated new skills and styles of collaborating in this generation to such degree that it has made them different (Kim, Knight, \& Crutsinger, 2009). However, studies also suggest that this generation is in need of constant supervision and guidance (Gursoy et al., 2013), prefer changing jobs multiple times, and they desire constant feedback with frequently added challenges (Hayes et al., 2018). Generation Y tends to be more open minded, liberal, and practical and values personal life (Park \& Park, 2018), besides they want work to be meaningful, and seek to contribute to a greater purpose (Dixon et al., 2013).

Finally, given these different management styles, such clashes have been in a sense predictable. See Table 2 for understanding the main features and events throughout different generations analyzed and their differences. 
Table 2: Main features throughout different generations (Dixon et al., 2013; Hatum, 2013)

\begin{tabular}{|c|c|c|c|}
\hline & Baby Boomers & Gen X & Millennials \\
\hline & $(1945-1964)$ & $(1965-1980)$ & $(1981-2000)$ \\
\hline \multirow[t]{4}{*}{ Main events } & Cold War & Berlin Wall taken down & September 11 \\
\hline & First man on the moon & AIDS & War in Afghanistan \\
\hline & Kennedy assassination & Drugs & Corporate scandals \\
\hline & Civil rights struggle & & \\
\hline \multirow{3}{*}{$\begin{array}{l}\text { Technology } \\
\text { evolution }\end{array}$} & TV & Personal computer & Social networks \\
\hline & & Mobile phone & Internet \\
\hline & & TV Cable & \\
\hline Slogan & $\begin{array}{l}\text { "What an amazing career } \\
\text { we built" }\end{array}$ & $\begin{array}{l}\text { "I have the capabilities, I } \\
\text { need to succeed" }\end{array}$ & $\begin{array}{l}\text { "We are going to rock the } \\
\text { workplace" }\end{array}$ \\
\hline \multirow{2}{*}{$\begin{array}{c}\text { Managerial } \\
\text { styles }\end{array}$} & Top-down & Self-control & Not yet fully developed \\
\hline & Build consensus & Competition & \\
\hline Loyalty & To the job & $\begin{array}{l}\text { To the profession, to the } \\
\text { boss }\end{array}$ & $\begin{array}{l}\text { To the project, colleagues, } \\
\text { boss }\end{array}$ \\
\hline \multirow[t]{3}{*}{ Rewards } & Money & Learning opportunities & A job with sense \\
\hline & Status & Work-life balance & Growth opportunities \\
\hline & Job titles & & Work-life integration \\
\hline \multirow[t]{3}{*}{ Values } & Competitiveness & Autonomy & Teamwork \\
\hline & Hardworking & Freedom & Flexibility \\
\hline & Optimistic & Individualism & Social awareness \\
\hline $\begin{array}{c}\text { Assume } \\
\text { Responsibility }\end{array}$ & \begin{tabular}{|llr} 
Willing to & invest \\
themselves & in & the \\
organizations & & \\
\end{tabular} & $\begin{array}{l}\text { Use teams to support } \\
\text { individual efforts and } \\
\text { relationships }\end{array}$ & $\begin{array}{l}\text { Accustomed to working in } \\
\text { teams, will assume } \\
\text { responsibility }\end{array}$ \\
\hline Serve & $\begin{array}{l}\text { Need to distinguish } \\
\text { themselves from peers, } \\
\text { extremely willing to serve } \\
\text { organization }\end{array}$ & $\begin{array}{l}\text { Relationships take } \\
\text { precedence over career }\end{array}$ & $\begin{array}{l}\text { Want clear direction, must } \\
\text { be challenged }\end{array}$ \\
\hline
\end{tabular}

\section{Methodology}

\section{Sample}

For the present investigation, 522 surveys were carried out to different employees of the logistic sector in Colombia. Respondents were comprised of 359 Millennials (68.8\%), 79 Gen Xers (15.1\%), and 84 Baby Boomers (16.1\%). They were $313(60.0 \%)$ males and 209 (40.0\%) females. Almost $69.3 \%$ of the respondents had been with the current company for less than 5 years. A random sampling was carried out in companies of different sizes (SMEs, medium and large companies) (see Table 3). 
Table 3: Relationship gender, time of permanence, company size and age

\begin{tabular}{|c|c|c|c|c|}
\hline \multirow{2}{*}{\multicolumn{2}{|c|}{ VARIABLE }} & Baby Boomers & Gen X & Millennials \\
\hline & & $(1945$ - 1964) & $(1965-1980)$ & $(1981-2000)$ \\
\hline \multirow{2}{*}{ GENDER } & Female & 29 & 24 & 156 \\
\hline & Male & 55 & 55 & 203 \\
\hline \multirow{5}{*}{$\begin{array}{c}\text { TIME OF } \\
\text { PERMANENCE }\end{array}$} & Less than 1 year & 8 & 7 & 101 \\
\hline & $1-3$ years & 14 & 18 & 130 \\
\hline & 3 - 5 years & 10 & 17 & 57 \\
\hline & 5 - 10 years & 17 & 18 & 51 \\
\hline & More than 10 years & 35 & 19 & 20 \\
\hline & & & & \\
\hline \multirow{3}{*}{ COMPANY SIZE } & Pyme & 30 & 15 & 76 \\
\hline & Medium & 28 & 17 & 109 \\
\hline & Large & 26 & 47 & 174 \\
\hline
\end{tabular}

\section{Instrument}

The instrument used in this research was the Wage and Subjective Conditions Assessing Tool performed by MartínezBuelvas et al (2016) that it has been wellvalidated in previous studies $(\alpha=0.898$; $\mathrm{KMO}=0.888$ and total variance $=$ $71.298 \%$ ). The instrument consists of 108 items: 14 on demographic conditions, 84 on the perceptions of salary and subjective conditions and 10 on behavior (Buelvas, Oviedo-Trespalacios, \& Amaya, 2016; Martínez-Buelvas, Oviedo-Trespalacios, \& Luna-Amaya, 2019). Participants were required to respond on a Likert scale from 1 to 10 according to their agreement with each of the statements presented, being 1 Totally Disagree and 10 Totally Agree.

\section{Data Analysis}

Internal consistency analysis was performed by calculating the Cronbach alpha coefficient in order to provide information about the relationships between individual items in the scale. Correlation analyses were conducted to examine the relationships between salary conditions variables, career development variables and subjective conditions variables. Finally, one-way ANOVA was employed to assess generational differences in quality of work life. Analyzes were conducted with the Statistical Package for Social Sciences (SPSS), version 24.0 for Windows.

\section{Results}

\section{Reliability Analysis}

Using Cronbach's alpha, it was possible to verify the consistency of the items since the values obtained were close to 1 , that is, they reflect a good reliability index. As results of the univariate analysis, an average of 8.073 and a standard deviation of 1.569 were obtained. The homogeneity of the data measured by Cronbach's alpha was greater than 0.927, consequently, there is statistical evidence of the high degree of reliability of the data collected.

\section{Correlation Analysis}

Correlation is a measure of the strength of the relationships between each of the variables; thus, in order to assess the magnitude and significance of the associations between the different variables of the study, we calculated the Pearson correlation coefficients. The results exhibit positive relationships with respect to $\mathrm{p}$-value less than 0.01 (see Table 4). 
Table 4: Pearson Correlations Coefficients

\begin{tabular}{|c|c|c|c|c|c|c|c|c|c|c|c|c|c|c|c|}
\hline Variable & 1 & 2 & 3 & 4 & 5 & 6 & 7 & 8 & 9 & 10 & 11 & 12 & 13 & 14 & 15 \\
\hline 1. Salary & 1 & $0.513^{*}$ & $0.314^{*}$ & $0.390^{*}$ & $0.404^{*}$ & $0.478^{*}$ & $0.394^{*}$ & $0.395^{*}$ & $0.452^{*}$ & $0.408^{*}$ & $0.320^{*}$ & $0.289^{*}$ & $0.291^{*}$ & $0.362^{*}$ & $0.404^{*}$ \\
\hline 2. Labor stability & & 1 & $0.363^{*}$ & $0.372^{*}$ & $0.339^{*}$ & $0.419^{*}$ & $0.401^{*}$ & $0.460^{*}$ & $0.452^{*}$ & $0.416^{*}$ & $0.370^{*}$ & $0.350^{*}$ & $0.328^{*}$ & $0.427^{*}$ & $0.435^{*}$ \\
\hline 3. Mental ability & & & 1 & $0.312^{*}$ & $0.460^{*}$ & $0.448^{*}$ & $0.409^{*}$ & $0.648^{*}$ & $0.567^{*}$ & $0.530^{*}$ & $0.573^{*}$ & $0.531^{*}$ & $0.455^{*}$ & $0.592^{*}$ & $0.471^{*}$ \\
\hline 4. Schedule & & & & 1 & $0.328^{*}$ & $0.367^{*}$ & $0.413^{*}$ & $0.364^{*}$ & $0.462^{*}$ & $0.420^{*}$ & $0.358^{*}$ & $0.313^{*}$ & $0.288^{*}$ & $0.334^{*}$ & $0.421^{*}$ \\
\hline 5. Promotion and career & & & & & 1 & $0.585^{*}$ & $0.414^{*}$ & $0.503^{*}$ & $0.522^{*}$ & $0.521^{*}$ & $0.386^{*}$ & $0.266^{*}$ & $0.312^{*}$ & $0.379^{*}$ & $0.451^{*}$ \\
\hline 6. Training and research & & & & & & 1 & $0.515^{*}$ & $0.563^{*}$ & $0.577^{*}$ & $0.534^{*}$ & $0.480^{*}$ & $0.338^{*}$ & $0.381^{*}$ & $0.467^{*}$ & $0.469^{*}$ \\
\hline 7. Private sphere and labor world & & & & & & & 1 & $0.497^{*}$ & $0.547^{*}$ & $0.506^{*}$ & $0.478^{*}$ & $0.379^{*}$ & $0.385^{*}$ & $0.427^{*}$ & $0.459^{*}$ \\
\hline 8. Individual and labor activity & & & & & & & & 1 & $0.657^{*}$ & $0.676^{*}$ & $0.659^{*}$ & $0.619^{*}$ & $0.552^{*}$ & $0.676^{*}$ & $0.647^{*}$ \\
\hline $\begin{array}{l}\text { 9. Individual and labor group: } \\
\text { organizational plan }\end{array}$ & & & & & & & & & 1 & $0.783^{*}$ & $0.732^{*}$ & $0.613^{*}$ & $0.517^{*}$ & $0.647^{*}$ & $0.623^{*}$ \\
\hline $\begin{array}{l}\text { 10. Individual and work group: } \\
\text { hierarchical plan }\end{array}$ & & & & & & & & & & 1 & $0.737^{*}$ & $0.592^{*}$ & $0.500^{*}$ & $0.638^{*}$ & $0.655^{*}$ \\
\hline $\begin{array}{l}\text { 11. Individual and work group: } \\
\text { technical plan }\end{array}$ & & & & & & & & & & & 1 & $0.699^{*}$ & $0.633^{*}$ & $0.693^{*}$ & $0.567^{*}$ \\
\hline $\begin{array}{l}\text { 12. Individual and work group: social } \\
\text { plan }\end{array}$ & & & & & & & & & & & & 1 & $0.553^{*}$ & $0.650^{*}$ & $0.637^{*}$ \\
\hline $\begin{array}{lll}\begin{array}{l}\text { 13. Support and collaboration } \\
\text { between units }\end{array} & \\
\end{array}$ & & & & & & & & & & & & & 1 & $0.661^{*}$ & $0.436^{*}$ \\
\hline $\begin{array}{l}\text { 14. Institution and management } \\
\text { function }\end{array}$ & & & & & & & & & & & & & & 1 & $0.546^{*}$ \\
\hline 15. Satisfaction & & & & & & & & & & & & & & & 1 \\
\hline
\end{tabular}

Laura MARTÍNEZ-BUELVAS and Olga JARAMILLO-NARANJO (2019), IBIMA Business Review, DOI: $10.5171 / 2019.493697$ 
The relationships found suggest for example:

- With the correlation coefficient of 0.783 for the organizational and hierarchical level, it can be deduced that when good relations are carried out and these are in favor to the constructive development of both the individual and the workgroup, it is executed a coupled work that makes prosper all departments of a company.

- Better training and research opportunities make that employee's mental state increases $(r=0,448)$.

- Better schedules make that employee's individual and labor group: organizational plan increases $(\mathrm{r}=$ 0,462).

- The perception of the individual according to his/her satisfaction increase as his/her salary and stability increases in the company $(r=0.395$ and $r=0.460$ respectively).

- The perception of the individual according to his/her satisfaction increases as his/her relationship with coworkers $(r=0.637)$.

- Finally, a greater job stability increases the perception of a good salary received for the work done $(r=0.513)$.

\section{One-way ANOVA Analysis}

From the perspective of generational differences, ANOVA with post hoc tests (Turkey's HSD) were conducted and showed that there are significant differences between the following variables of quality of labor life among the three generations (see Table 5).

Table 5: One-way ANOVA for mean difference in quality of work life for three generations

\begin{tabular}{|c|c|c|c|c|c|c|c|}
\hline \multicolumn{2}{|l|}{ Variables } & & \multirow{2}{*}{$\frac{\text { Mean }}{8.218}$} & \multirow{2}{*}{\begin{tabular}{|l|} 
SD \\
1.672
\end{tabular}} & \multirow{2}{*}{\begin{tabular}{|l|}
$\begin{array}{l}\text { Between } \\
\text { groups }\end{array}$ \\
\end{tabular}} & \multirow{2}{*}{\begin{tabular}{|l|} 
df \\
2
\end{tabular}} & \multirow{2}{*}{\begin{tabular}{|l}
$\mathbf{F}$ \\
$6.515^{*}$
\end{tabular}} \\
\hline 1. Salary & \begin{tabular}{|l|} 
Baby \\
Boomers \\
\end{tabular} & & & & & & \\
\hline & Gen Xers & 79 & 7.474 & 1.872 & Within groups & 519 & \\
\hline & Millennials & 359 & 7.371 & 2.011 & Total & 521 & \\
\hline & Total & 522 & 7.523 & 1.960 & & & \\
\hline \multirow[t]{4}{*}{ 2. Labor stability } & $\begin{array}{l}\text { Baby } \\
\text { Boomers }\end{array}$ & 84 & 7.817 & 1.172 & \begin{tabular}{|l} 
Between \\
groups
\end{tabular} & 2 & $5.889^{*}$ \\
\hline & Gen Xers & 79 & 7.411 & 1.248 & Within groups & 519 & \\
\hline & Millennials & 359 & 7.206 & 1.594 & Total & 521 & \\
\hline & Total & 522 & 7.336 & 1.499 & & & \\
\hline \multirow[t]{4}{*}{ 3. Mental ability } & \begin{tabular}{|l} 
Baby \\
Boomers \\
\end{tabular} & 84 & 8.985 & 1.216 & \begin{tabular}{|l|} 
Between \\
groups
\end{tabular} & 2 & 2.081 \\
\hline & Gen Xers & 79 & 8.658 & 1.487 & Within groups & 519 & \\
\hline & Millennials & 359 & 8.626 & 1.504 & Total & 521 & \\
\hline & Total & 522 & 8.689 & 1.462 & & & \\
\hline \multirow[t]{4}{*}{ 4. Schedule } & $\begin{array}{l}\text { Baby } \\
\text { Boomers }\end{array}$ & 84 & 7.359 & 1.530 & \begin{tabular}{|l} 
Between \\
groups
\end{tabular} & 2 & 0.962 \\
\hline & Gen Xers & 79 & 7.013 & 1.624 & Within groups & 519 & \\
\hline & Millennials & 359 & 7.180 & 1.603 & Total & 521 & \\
\hline & Total & 522 & 7.183 & 1.595 & & & \\
\hline \multirow[t]{4}{*}{$\begin{array}{l}\text { 5. Promotion and } \\
\text { career }\end{array}$} & \begin{tabular}{|l|} 
Baby \\
Boomers \\
\end{tabular} & 84 & 7.645 & 1.867 & \begin{tabular}{|l|}
$\begin{array}{l}\text { Between } \\
\text { groups }\end{array}$ \\
\end{tabular} & 2 & $3.147^{* *}$ \\
\hline & Gen Xers & 79 & 6.934 & 2.206 & Within groups & 519 & \\
\hline & Millennials & 359 & 7.441 & 1.839 & Total & 521 & \\
\hline & Total & 522 & 7.397 & 1.911 & & & \\
\hline $\begin{array}{ll}6 . & \text { Training }\end{array}$ & Baby & 84 & 7.938 & 1.872 & Between & 2 & 2.964 \\
\hline
\end{tabular}




\begin{tabular}{|c|c|c|c|c|c|c|c|}
\hline \multirow[t]{4}{*}{ research } & Boomers & & & & groups & & \\
\hline & Gen Xers & 79 & 7.154 & 2.347 & Within groups & 519 & \\
\hline & Millennials & 359 & 7.617 & 2.048 & Total & 521 & \\
\hline & Total & 522 & 7.599 & 2.077 & & & \\
\hline \multirow[t]{4}{*}{$\begin{array}{l}\text { 7. Private sphere and } \\
\text { labor world }\end{array}$} & $\begin{array}{l}\text { Baby } \\
\text { Boomers }\end{array}$ & 84 & 8.429 & 1.432 & \begin{tabular}{|l}
$\begin{array}{l}\text { Between } \\
\text { groups }\end{array}$ \\
\end{tabular} & 2 & $3.173^{* *}$ \\
\hline & Gen Xers & 79 & 8.146 & 1.688 & Within groups & 519 & \\
\hline & Millennials & 359 & 7.955 & 1.593 & Total & 521 & \\
\hline & Total & 522 & 8.060 & 1.590 & & & \\
\hline \multirow[t]{4}{*}{$\begin{array}{l}\text { 8. Individual and labor } \\
\text { activity }\end{array}$} & $\begin{array}{l}\text { Baby } \\
\text { Boomers }\end{array}$ & 84 & 8.554 & 1.314 & \begin{tabular}{|l|}
$\begin{array}{l}\text { Between } \\
\text { groups }\end{array}$ \\
\end{tabular} & 2 & $8.180^{*}$ \\
\hline & Gen Xers & 79 & 8.063 & 1.361 & Within groups & 519 & \\
\hline & Millennials & 359 & 7.908 & 1.311 & Total & 521 & \\
\hline & Total & 522 & 8.036 & 1.337 & & & \\
\hline \multirow{4}{*}{$\begin{array}{l}\text { 9. Individual and labor } \\
\text { group: organizational } \\
\text { plan }\end{array}$} & \begin{tabular}{|l} 
Baby \\
Boomers
\end{tabular} & 84 & 8.906 & 1.130 & \begin{tabular}{|l|}
$\begin{array}{l}\text { Between } \\
\text { groups }\end{array}$ \\
\end{tabular} & 2 & 2.454 \\
\hline & Gen Xers & 79 & 8.574 & 1.131 & Within groups & 519 & \\
\hline & Millennials & 359 & 8.569 & 1.335 & Total & 521 & \\
\hline & Total & 522 & 8.624 & 1.278 & & & \\
\hline \multirow{4}{*}{$\begin{array}{l}10 . \text { Individual and } \\
\text { work group: } \\
\text { hierarchical plan }\end{array}$} & \begin{tabular}{|l|} 
Baby \\
Boomers \\
\end{tabular} & 84 & 9.054 & 1.346 & \begin{tabular}{|l|}
$\begin{array}{l}\text { Between } \\
\text { groups }\end{array}$ \\
\end{tabular} & 2 & $5.775^{*}$ \\
\hline & Gen Xers & 79 & 8.268 & 1.685 & Within groups & 519 & \\
\hline & Millennials & 359 & 8.499 & 1.595 & Total & 521 & \\
\hline & Total & 522 & 8.553 & 1.587 & & & \\
\hline \multirow{4}{*}{$\begin{array}{l}11 . \quad \text { Individual and } \\
\text { work group: technical } \\
\text { plan }\end{array}$} & \begin{tabular}{|l|} 
Baby \\
Boomers \\
\end{tabular} & 84 & 9.082 & 0.982 & \begin{tabular}{|l|}
$\begin{array}{l}\text { Between } \\
\text { groups }\end{array}$ \\
\end{tabular} & 2 & $5.684^{*}$ \\
\hline & Gen Xers & 79 & 8.553 & 1.312 & Within groups & 519 & \\
\hline & Millennials & 359 & 8.549 & 1.395 & Total & 521 & \\
\hline & Total & 522 & 8.635 & 1.337 & & & \\
\hline \multirow[t]{4}{*}{$\begin{array}{l}\text { Individual and } \\
\text { work group: social plan }\end{array}$} & \begin{tabular}{|l} 
Baby \\
Boomers \\
\end{tabular} & 84 & 8.895 & 1.034 & \begin{tabular}{|l|}
$\begin{array}{l}\text { Between } \\
\text { groups }\end{array}$ \\
\end{tabular} & 2 & $4.538^{* *}$ \\
\hline & Gen Xers & 79 & 8.622 & 1.203 & Within groups & 519 & \\
\hline & Millennials & 359 & 8.438 & 1.346 & Total & 521 & \\
\hline & Total & 522 & 8.539 & 1.288 & & & \\
\hline \multirow{4}{*}{$\begin{array}{l}\text { 13. Support and } \\
\text { collaboration between } \\
\text { units }\end{array}$} & \begin{tabular}{|l|} 
Baby \\
Boomers
\end{tabular} & 84 & 8.706 & 1.328 & \begin{tabular}{|l|}
$\begin{array}{l}\text { Between } \\
\text { groups }\end{array}$ \\
\end{tabular} & 2 & $3.659^{* *}$ \\
\hline & Gen Xers & 79 & 8.363 & 1.552 & Within groups & 519 & \\
\hline & Millennials & 359 & 8.162 & 1.784 & Total & 521 & \\
\hline & Total & 522 & 8.280 & 1.693 & & & \\
\hline \multirow[t]{4}{*}{$\begin{array}{l}\text { 14. Institution and } \\
\text { management function }\end{array}$} & \begin{tabular}{|l|} 
Baby \\
Boomers \\
\end{tabular} & 84 & 9.238 & 1.045 & \begin{tabular}{|l|}
$\begin{array}{l}\text { Between } \\
\text { groups }\end{array}$ \\
\end{tabular} & 2 & $7.775^{*}$ \\
\hline & Gen Xers & 79 & 8.717 & 1.378 & Within groups & 519 & \\
\hline & Millennials & 359 & 8.561 & 1.500 & Total & 521 & \\
\hline & Total & 522 & 8.693 & 1.437 & & & \\
\hline \multirow[t]{3}{*}{ 15. Satisfaction } & \begin{tabular}{|l|} 
Baby \\
Boomers \\
\end{tabular} & 84 & 8.239 & 1.487 & \begin{tabular}{|l|}
$\begin{array}{l}\text { Between } \\
\text { groups }\end{array}$ \\
\end{tabular} & 2 & 2.555 \\
\hline & Gen Xers & 79 & 7.723 & 1.502 & Within groups & 519 & \\
\hline & Millennials & 359 & 7.933 & 1.475 & Total & 521 & \\
\hline
\end{tabular}

Laura MARTÍNEZ-BUELVAS and Olga JARAMILLO-NARANJO (2019), IBIMA Business Review, DOI: $10.5171 / 2019.493697$ 


\begin{tabular}{|l|l|l|l|l|l|l|l|l|}
\hline & Total & 522 & 7.950 & 1.486 & & & & \\
\hline${ }^{*} \mathrm{p}<0.01 ; * * \mathrm{p}<0.05$
\end{tabular}

The relationships found suggest:

- Employees perceive salary as the remuneration received for a job performed and Labor Stability as the right to keep his/her job while not incurring in any of the grounds for dismissal established by law (Casas, Repullo, Lorenzo, \& Cañas, 2002). In this case, Baby Boomers had significantly higher scores than Gen Xers and Millennials (F-value $=6.515, \mathrm{p}$ $<0.01$; F-value $=5.889, \mathrm{p}<0.01$ respectively). Molinari (2012) expresses that Baby Boomers value safety and live to work, otherwise, Millennials and Gen Xers value more their personal and family project.

- Promotion and career opportunities are a tool for managing human talent, helping to retain employees (MartínezBuelvas, Jaramillo-Naranjo, GamarraAmarís, Llinás-Herrera, \& JiménezPérez, 2017). Millennials scored significantly higher on this dimension than Gen Xers (F-value $=3.147, \mathrm{p}<$ 0.05 ) because they see work as an enjoyment and always are looking for new opportunities to learn and exploit their capabilities (Jorgensen, 2003; Weirich, 2017).

- $\quad$ Private sphere and labor world refers to the problems that can occur within the workplace. Otherwise, Individual and labor activity talks about to the opportunities that the job offers in order to develop knowledge or skills (Casas et al., 2002). For Baby Boomers and Gen Xers these dimensions are more important than Millennials (Fvalue $=3.173, \mathrm{p}<0.05 ; \mathrm{F}$-value $=8.180$, $\mathrm{p}<0.01$ respectively)

- Individual and work group: hierarchical plan is the relationship between the individual and his/her superiors or persons in charge, which allows the optimal execution of the organizational goals (Martínez-Buelvas et al., 2017). Millennials and Baby Boomers scored significantly higher than Gen Xers (F-value $=5.775, \mathrm{p}<$ 0.01). This result corroborates the literature, given that Baby Boomers respect hierarchical levels and their identity is based on work, as well as, for Millennials, participation in decisions is an acquired right (Molinari, 2012).

- Individual and work group: technical plan refers to the participation and communication that the individual has in his/her work environment by performing his/her functions and responsibilities (Martínez-Buelvas et al., 2017). Gen Xers scored significantly higher than Millennials (F-value $=$ 5.684, $\mathrm{p}<0.01$ ) and this is because they measure commitment with the results obtained and not with the time spent in the office (Molinari, 2012).

- Individual and work group: social plan refers to fellowship relationships. Gen Xers scored significantly higher than Millennials (F-value $=4.538, \mathrm{p}<0.05$ ). This means that they value the time dedicated to family, friends and everything that gives them pleasure (Molinari, 2012).

- Baby Boomers had significantly higher scores on Support and collaboration between units and Institution and management function than Gen Xers and Millennials (F-value $=53.659, \mathrm{p}<$ 0.05; F-value $=7.775, \mathrm{p}<0.01$ respectively). This means that they appreciate horizontal cooperation within the institution, and respect media in order to communicate and participate between coworkers (Hayes et al., 2018; Sue Ling et al., 2012).

We can ratify that generational differences in quality of work life exist between older and younger generations of employees in the logistics sector. Those generational differences can be viewed as an obstacle or an opportunity to improve the workplace (Gursoy et al., 2013). Some managers may see those differences as superficial and may ignore them. However, those differences may have a substantial influence on workplace attitudes, and influence interactions between employees and managers, employees and customers, 
and employees and employees. If managers and coworkers do not understand each other's generational differences, tension among employees is likely to increase, and job satisfaction and productivity are likely to decrease (Kupperschmidt, 2000). On the other hand, managers who understand those differences and the priorities of each generation are likely to create a workplace environment that foster leadership, motivation, communication and generational synergy (Wey Smola \& Sutton, 2002).

The results also conclude that the statement of Patterson and Pegg (2009) is valid in the sense that Baby Boomers generation is focused on stability, respect for authority, dedication to work, payment and orientation to achievements (Almeida, 2012). While the assertion from Generation $\mathrm{X}$ is also validated by Kupperschmidt (2000), because this generation is skeptical of authority and hierarchical relationships and more individualistic (Lombardía et al., 2008). Finally, with the Millennials, it is confirmed that their strength is towards group work, freedom to make decisions and balance work and family (Yeaton et al., 2008).

Finally, HRM can apply the following strategies in order to manage these generations, for example, one way to motivate and retain Baby Boomers is designing fair and attractive compensation models, in which salaries are competitive and commensurate with the functions and responsibilities of the job. As well, designing strategies for retirement in which they feel that their hard work was rewarded, because this generation lives to work. In terms of Gen Xers, it is important to design models of job flexibility, in which they can manage their time and thus balance their work and personal life, additional, create spaces in which they can discuss with their peers relevant labor issues and not feel that they are wasting time. On the other hand, Millennials can be attracted and retained by designing career plans that allow them to develop their skills quickly, offering work flexibility, working from home and designing innovative and challenging jobs.

\section{Conclusion}

Organizations are taking different forms and shapes as never seen before. Recent changes that companies have gone through and additional changes likely to come in the future will help them understand how to manage the new workforce entering companies. Findings of this study provided evidence that differences in perception of quality of work life among employees from different generations exist. Awareness of those differences among generations can help managers to create more pleasant and productive workplace, to manage new generations and design new ways to organize such that they can successfully respond to a dynamic, changeable external environment. Results suggested that Baby Boomers respect authority, and hierarchy, while Millennials tend to challenge authority. Findings also suggest that while Baby Boomers and Gen Xers live to work, Millennials work to live.

This study is one-step further toward a thorough understanding of generational differences and similarities among employees of the logistic sector in Colombia. Identification of generational issues is likely to result in the development of leadership strategies that increases employee morale and productivity by lowering workplace tensions and generational conflicts in the workplace. Therefore, this study holds the potential for helping companies and managers to better understand generational issues in the workplace. In addition, the results of the study will hope serve as a base for more comprehensive research.

Finally, it would be interesting to conduct research where the employees' quality of life of different generations in different sectors can be compared, in order to determine whether or not there are substantial differences, as well as, to make inquiries concerning the different behaviors of each generation in the plans addressed by the QWL construct. In addition, it is recommended that future studies discuss how the knowledge on each generation in the workplace can inform specific HRM practices, such as how to 
train each generation effectively or to encourage each generation to improve work performance. Besides, it is important to mention that an exhaustive search of articles was carried out to identify differences or similitude between these generations in Colombia, but there is no available literature. Thus, our findings regarding, if quality of work life significantly differs among three generational cohorts in the logistic sector are rather preliminary and future research is necessary to confirm this assertion.

\section{Acknowledgment}

This research received no specific grant from any funding agency in the public, commercial, or not-for-profit sectors. Some of the contributions presented in this work were communicated and published in the scientific paper "Martinez-Buelvas, L., Jaramillo-Naranjo, O. \& Oviedo-Trespalacios, O. (2019) Generational Diversity and Quality of Work Life: Case Study in the Colombian Logistic Sector. Proceedings of the 33rd International Business Information Management Association Conference, Education Excellence and Innovation Management through Vision 2020, pp 936946"

\section{References}

1. Almeida, G. M. E. (2012). Trayectoria profesional de la generación de los "Baby Boomers". In. Universidad Andina Simón Bolívar Sede Ecuador, Quito, Ecuador.

2. Argüelles Ma, L. A., Garcia, R. A. Q., Fajardo, M. J., Medina, D. E. M., \& Maldonado, J. A. S. (2013). Propuesta de Modelo Predictivo de la Calidad de Vida Laboral en el Sector Turístico Campechano (México). Institute for Business \& Finance Research, 8(2), 488-494.

3. Bagtasos, M. R. (2011). Quality of Work Life: A Review of Literature. DLSU Business \& Economics Review, 20(2), 1-8.

4. Buelvas, L. M., Oviedo-Trespalacios, O., \& Amaya, C. L. (2013). Working conditions impacting quality of work life,Condiciones de trabajo que impactan en la vida laboral. Salud Uninorte, 29(3), 542-560.

5. Buelvas, L. M., Oviedo-Trespalacios, O., \& Amaya, C. L. (2016). Design and validation of an instrument to measure the perception of working conditions: Case manufacturing sector Colombian Caribbean Region,Diseño y validación de una herramienta para medir la percepción de las condiciones de trabajo: Caso Sector manufacturero de la región Caribe colombiana. Universitas Psychologica, 15(1), 339-348. doi:10.11144/Javeriana.upsy15-1.dvhm

6. Cardona Echeverri, D. R., \& Zambrano Cruz, R. (2014). Revisión de instrumentos de evaluación de clima organizacional. Estudios Gerenciales, 30(131), 184-189. doi:https://doi.org/10.1016/j.estger.2014. $\underline{04.007}$

7. Casas, J., Repullo, J. R., Lorenzo, S., \& Cañas, J. J. (2002). Dimensiones y medición de la calidad de vida laboral en profesionales sanitarios. Revista de administración sanitaria, 6(23), 143-160.

8. Celia, B. R., \& Karthick, M. (2012). A Study On Quality Of Work Life In The IT Sector. Asia Pacific Journal of Research in Business Management, 3(2), 1-1.

9. Dixon, G., Mercado, A., \& Knowles, B. (2013). Followers and Generations in the Workplace. Engineering Management Journal, 25(4), 62-72. doi:10.1080/10429247.2013.11431996

10.Gursoy, D., Chi, C. G.-Q., \& Karadag, E. (2013). Generational differences in work values and attitudes among frontline and service contact employees. International Journal of Hospitality Management, 32, 4048.

doi:https://doi.org/10.1016/j.ijhm.2012.0 $\underline{4.002}$

11.Hatum, A. (2013). The new workforce challenge how today's leading companies are adapting for the future. Basingstoke: Palgrave Macmillan. 
12.Hayes, J. B., Parks, C., McNeilly, S., \& Johnson, P. (2018). Boomers to Millennials: Generational Stereotypes at Work in Academic Librarianship. The Journal of Academic Librarianship, 44(6), 845-853. doi:https://doi.org/10.1016/i.acalib.2018. $\underline{09.011}$

13.Jorgensen, B. (2003). Baby Boomers, Generation X and Generation Y?: Policy implications for defence forces in the modern era. Foresight, 5(4), 41-49. doi:10.1108/14636680310494753

14.Kim, H., Knight, D. K., \& Crutsinger, C. (2009). Generation Y employees' retail work experience: The mediating effect of job characteristics. Journal of Business Research, 62(5), 548-556. doi:10.1016/j.jbusres.2008.06.014

15.Kultalahti, S., \& Liisa Viitala, R. (2014). Sufficient challenges and a weekend ahead - Generation Y describing motivation at work. Journal of Organizational Change Management, 27(4), 569-582. doi:10.1108/JOCM-05-2014-0101

16.Kupperschmidt, B. R. (2000). Multigeneration employees: strategies for effective management. Health Care Manag (Frederick), 19(1), 65-76.

17.Lombardía, P. G., Stein, G., Pin, J. (2008). Políticas para dirigir a los nuevos profesionales-motivaciones y valores de la generación Y. In. Recuperado de https://www.iese.edu/ research/pdfs/DI0753.pdf.

18.Martínez-Buelvas, L., Jaramillo-Naranjo, 0., Gamarra-Amarís, O., Llinás-Herrera, A., \& Jiménez-Pérez, F. (2017, 2017). Perception of working conditions on the quality of working life: Employees linked to health companies in Barranquilla, Colombia. Paper presented at the Proceedings of the 30th International Business Information Management Association Conference, IBIMA 2017 - Vision 2020: Sustainable Economic development, Innovation Management, and Global Growth.

19.Martínez-Buelvas, L., $\quad$ OviedoTrespalacios, O., \& Luna-Amaya, C. (2015).
Impact of working conditions on the quality of working life: Case manufacturing sector colombian Caribbean Region. Dyna. doi:10.15446/dyna.v82n194.49293

20.Martínez-Buelvas, L., OviedoTrespalacios, O., \& Luna-Amaya, C. (2019). Herramienta de evaluación del impacto de las condiciones salariales y subjetivas en la calidad de vida laboral: Caso Sector Manufacturero de la Región Caribe Colombiana. Paper presented at the Proceedings of the 32nd International Business Information Management Association Conference, IBIMA 2018 Vision 2020: Sustainable Economic Development and Application of Innovation Management from Regional expansion to Global Growth.

21.Molinari, P. (2012). Turbulencia Generacional: Temas Grupo Editorial.

22.Ng, E. S. W., Schweitzer, L., \& Lyons, S. T. (2010). New generation, great expectations: A field study of the millennial generation. Journal of Business and Psychology, 25(2), 281-292. doi:10.1007/s10869-010-9159-4

23.0'Bannon, G. (2001). Managing Our Future: The Generation X Factor. Public Personnel Management, 30(1), 95-110. doi:10.1177/009102600103000109

24.Park, S., \& Park, S. (2018). Exploring the generation gap in the workplace in South Korea. Human Resource Development International, 21(3), 276-283. doi:10.1080/13678868.2017.1306769

25.Patlán Pérez, \& J. (2016). Calidad de vida laboral. México: El Manual Moderno S.A.

26.Patterson, I., \& Pegg, S. (2009). Marketing the Leisure Experience to Baby Boomers and Older Tourists. Journal of Hospitality Marketing \& Management, 18(23), 254-272. doi:10.1080/19368620802594136

27.Quezada, F. Q., Castro, A. S., \& Cabezas, F. S. (2010). Diagnóstico de la Calidad de Vida Laboral Percibida por los Trabajadores de Cuatro Servicios Clínicos del Complejo 
Asistencial Dr. Víctor Ríos Ruiz., 9(1), 5568.

28.Schuman, H., \& Scott, J. (1989). Generations and Collective Memories. American Sociological Review, 54(3), 359381. doi: $10.2307 / 2095611$

29.Seaton, L. J., Boyd, M. (2007). The organizational leadership of the post baby boom generation: an upper echelon theory approach.. Academy of Entrepreneurship Journal, 13(2), 69-77.

30.Segurado Torres, A., \& Agulló Tomás, E. (2002). Calidad de vida laboral: hacia un enfoque integrador desde la psicología social. In (Vol. 14, pp. 828-836): Colegio Oficial de Psicólogos del Principado de Asturias 2002.

31.Silva, M. d. (2006). Nuevas perspectivas de la calidad de vida laboral y sus relaciones con la eficacia organizacional. (Dissertation/Thesis). Universitat de Barcelona, Retrieved from http://search.ebscohost.com/login.aspx?di rect=true \&db=edstdx\&AN=tdx.10803.2669 $\langle=$ es\&site=eds-live Available from EBSCOhost edstdx database.

32.Somarriba Arechavala, N., Merino Llorente, M. C., Ramos Truchero, G., \& Negro Macho, A. (2010). La calidad del trabajo en la Unión Europea. Estudios de Economia Aplicada, 28(3). doi:http://www.revista-eea.net

33.Sue Ling, L., Chang, J., \& Lien Yin, H. (2012). Does Effect of Workload on Quality of Work Life Vary With Generations? Asia Pacific Management Review, 17(4), 437451. doi:10.6126/APMR.2012.17.4.06

34.Tang, N., Wang, Y., \& Zhang, K. (2017). Values of Chinese generation cohorts: Do they matter in the workplace? Organizational Behavior and Human Decision Processes, 143, 8-22. doi:https://doi.org/10.1016/i.obhdp.2017. $\underline{07.007}$
35.Twenge, J. M., \& Campbell, W. K. (2003). "Isn't it fun to get the respect that we're going to deserve?" Narcissism, social rejection, and aggression. Pers Soc Psychol Bull, 29(2), 261-272. doi:10.1177/0146167202239051

36.Van der Berg, Y., \& Martins, N. (2013). The relationship between organisational trust and quality of work life. South African Journal of Human Resource Management, 11(1), 1-13. doi:10.4102/sajhrm.v11i1.392

37.Vélez, M. A. G. (2010). Calidad De Vida Laboral En Empleados Temporales Del Valle De Aburrá - Colombia. (Spanish). Quality of Working Life In Temporary Employees Aburrá Valley - Colombia. (English), 18(24), 225-236.

38.Weirich, B. (2017). A Millennial Leader's Views on the Millennial Workforce. Nurse Leader, 15(2), 137-139. doi:https://doi.org/10.1016/j.mnl.2016.12 $\underline{.003}$

39.Wey Smola, K., \& Sutton, C. D. (2002). Generational differences: revisiting generational work values for the new millennium. Journal of Organizational Behavior, 23(4), 363-382. doi:10.1002/job.147

40.Wittig-Berman, U., \& Beutell, N. J. (2008). Work-family conflict and work-family synergy for generation $\mathrm{X}$, baby boomers, and matures: Generational differences, predictors, and satisfaction outcomes. Journal of Managerial Psychology, 23(5), 507-523. doi:10.1108/02683940810884513

41.Yeaton, K. (2008). Recruiting and managing the'why?'generation: Gen Y.. The CPA Journal, 78(4), 68.

42.Zemke, R., Raines, C., \& Filipczak, B. (2013). Generations at work: Managing the clash of Boomers, Gen Xers, and Gen Yers in the workplace. . 